\title{
Epigallocatechin-3 gallate induces growth inhibition and apoptosis in human breast cancer cells through survivin suppression
}

\author{
YAN TANG, DANIEL Y.ZHAO, STEVEN ELLIOTT, WEIQIANG ZHAO, TYLER J. CURIEL, \\ BARBARA S. BECKMAN and MATTHEW E. BUROW \\ Department of Medicine, Section of Hematology and Medical Oncology, Department of Pharmacology, \\ Department of Surgery, Center for Bioenvironmental Research, Tulane Cancer Center, \\ Tulane University Health Sciences Center, New Orleans, LA 70112, USA
}

Received February 1, 2007; Accepted March 14, 2007

\begin{abstract}
Recent investigations have demonstrated that polyphenolic catechins inhibit cancer cell proliferation and tumor growth. However, how the major active component of tea catechins, epigallocatechin-3 gallate (EGCG), mediates anticancerous effects has not been extensively examined. We have investigated the cell growth inhibitory effects of EGCG on cell growth of the human breast cancer cell line MCF-7, and the mechanism of its action with emphasis on the regulation of tumor cell survival. A significant EGCG dose-dependent growth inhibition was observed coordinated with EGCG-induced apoptosis. Analysis of survivin expression after addition of EGCG showed that both survivin mRNA and protein were decreased. The survivin-promoter luciferase activity in EGCG-treated cells was significantly inhibited by $91 \pm 2.0 \%(\mathrm{P}<0.001)$, compared with the control. Interestingly, EGCG strongly inhibited the basal activation of phospho-AKT and AKT kinase activity as early as 30 min after treatment. Furthermore, inhibition of AKT kinase activity by EGCG preceded the suppression of survivin ( $1 \mathrm{~h}$ post treatment), followed by increased caspase- 9 activity ( 6 h post treatment). A dominant negative AKT or the phosphatidylinositol 3kinase inhibitor, LY294002, also strongly inhibited survivin promoter activity, providing further evidence to support the hypothesis that the inhibitory effect of EGCG on survivin is mediated via the AKT pathway. Therefore, EGCG is a potent proapoptotic agent in MCF-7 breast cancer cells that targets survivin expression via suppression of the AKT pathway.
\end{abstract}

Correspondence to: Dr Matthew E. Burow, Department of Medicine, Section of Hematology and Medical Oncology, Tulane University Health Sciences Center, 1430 Tulane Ave. (SL-78), New Orleans, LA 70112, USA

E-mail: mburow@tulane.edu

Key words: breast cancer, green tea, epigallocatechin-3 gallate, survivin, AKT, apoptosis

\section{Introduction}

Both epidemiological and laboratory studies have positively shown an association of tea consumption with lower risk for certain types of cancers (1-4). The cancer preventive and therapeutic potential of tea has received more attention in recent years largely due to the purification and studies of the effective anti-tumorigenic component, the tea polyphenols, known as catechins. There are four major catechins in green tea of which the most effective and predominant component is epigallocatechin-3 gallate (EGCG). Previous studies have shown that plasma concentration of EGCG reached a peak level between 1.5 and $2.5 \mathrm{~h}$ after drinking beverages containing 1.5-4.5 g dried green tea (DGT) (about 400-1500 mg EGCG) (5-8). Steady-state plasma levels of EGCG can be maintained with daily beverage drinking (7). Not only could EGCG inhibit tumor progression at different stages including cancer initiation, promotion, and progression but it could suppress different types of carcinomas such as skin, lung, oral cavity, esophagus, stomach, small intestine, colon, and pancreas (9-19). Breast cancer will affect 175,000 women and 1300 men in the US each year as estimated by the American Cancer Society. Although the epidemiologic studies showed a possible association of tea consumption in Asian Americans and a lower incidence of breast cancer (20), mixed laboratory results were reported (21). However, direct or indirect inhibitory effects of EGCG on mammary tumor cells have been reported though the mechanisms are still not clear (22-24).

The proposed advantage of EGCG as a chemopreventive agent relies on its selective elimination of transformed or neoplastic cells, while sparing or in some cases protecting normal cells $(19,25,26)$. This selectivity may be rooted in EGCG's ability to target abnormally expressed cell signaling or anti-apoptotic proteins in tumor cells but not in normal cells.

Survivin, a member of the inhibitor of apoptosis (IAP) family of proteins, is one such target that is widely expressed in fetal tissues and in human cancers, but is nearly absent or found at miniscule levels in normal adult tissues (27-33). Survivin contains a baculovirus inhibitor of apoptosis repeat (BIR) protein domain that inhibits apoptosis by either directly or indirectly interfering with the function of caspases (27). The tumor-specific expression of survivin, coupled with its 
importance in inhibiting cell death makes it a useful diagnostic marker of cancer and a potential target for cancer treatment. In studies of primary breast carcinoma (34), especially ductal carcinoma (35), survivin is overexpressed and may serve as a prognostic indicator of worse outcome (36). Studies by Altieri's group have shown that a dominant negative mutant survivin (pAd-T34A) inhibited growth of established tumors and triggered tumor cell apoptosis $(37,38)$ in vivo while wild-type survivin inhibited growth factor withdrawal- and ceramide-induced apoptosis. Therefore, survivin may be a valid target for EGCG in human breast cancers.

In this report we demonstrate that EGCG exerts its inhibitory activity in breast cancer via its ability to promote apoptosis through selectively inhibiting survival/anti-apoptotic pathways in breast cancer cell line, MCF-7, by direct or indirect suppression of survivin mRNA and protein.

\section{Materials and methods}

Cell culture. MCF-7 cells (N variant) (39) were maintained and grown in a $10 \%$ completed medium (Dulbecco's modified Eagle's medium (DMEM) supplemented with $10 \%$ fetal bovine serum (FBS), BME amino acids, MEM amino acids, glutamine, penicillin/streptomycin, sodium pyruvate (Invitrogen, Carlsbad, CA) under mycoplasma-free conditions. MCF-7 cells were grown for 2 days in a 5\% CS medium (DMEM phenolred-free, with 5\% dextran-coated charcoal stripped FBS) containing BME amino acids, MEM amino acids, glutamine, penicillin/streptomycin, sodium pyruvate.

Colony assay. Cells were dispersed into 6-well plates containing 500 cells/well. To each well of the 6-well plates, $2 \mathrm{ml}$ of the $5 \% \mathrm{CS}$ growth medium was added. Plates were incubated in a $5 \% \mathrm{CO}_{2}$ incubator at $37^{\circ} \mathrm{C}$. After $24 \mathrm{~h}$ of growth, the cells were treated with EGCG (LKT lab, St. Paul, $\mathrm{MN}$ ) with increasing concentrations of $10-50 \mu \mathrm{g} / \mathrm{ml}$ for $48 \mathrm{~h}$. Treatment-containing media were removed after $48 \mathrm{~h}$ and replaced with fresh $10 \%$ FBS complete medium, and then the cells were cultured for $\sim 14$ days. The cells were fixed with $5 \%$ gluteraldehyde for $10 \mathrm{~min}$, washed with PBS once, and then stained with $5 \%$ crystal violet for $20 \mathrm{~min}$. The numbers of colonies ( $\geq 50$ cells) were counted with an Oxford Optronix COLcount (Oxford, UK).

Viability assay. MCF-7 cells were plated in 96-well plates at $1 \times 10^{4}$ cells per well in $10 \%$ DMEM. The cells were allowed to adhere for $48 \mathrm{~h}$ and were treated appropriately. Forty-eight hours later the media was removed, and the cells were stained with $0.1 \mathrm{ml}$ of $0.5 \%$ crystal violet solution for $10 \mathrm{~min}$, washed with PBS to remove excess crystal violet and lysed in $0.1 \mathrm{ml}$ of $0.1 \%$ SDS solution. Absorbance at $540 \mathrm{nM}$ was measured using a 96-well microplate reader. Percent viability was determined based on normalization to untreated control cells (set at $100 \%$ ). Decreased viability represents a decrease in percentage of staining as compared with $100 \%$ control values.

Apoptotic assay. The MCF-7 cells were grown to $80 \%$ confluence in a 4-well chamber slide (Nalge Nunc, Naperville, IL) and treated with or without $50 \mu \mathrm{g} / \mathrm{ml}$ EGCG for $48 \mathrm{~h}$. Cells were washed twice with PBS and then stained by an
Annexin-V apoptosis detection kit (Molecular Probes, Eugene, OR) as instructed by the manufacturer's protocol. FITC-stained apoptotic cells were examined using fluorescence microscopy (Leica, Wetzlar, Germany).

Transient transfection and luciferase assay. The luciferase reporter construct of the survivin promoter consisted of a full-length unencoded region of the survivin promoter ligated to the promoterless firefly luciferase gene to create the construct pGL3-survivin-luciferase plasmid (SP13-Luc) (a generous gift of Dr Suxing Liu, Schering-Plough Research Institute, Kenilworth, NJ) (40). Specifically, MCF-7 cells were seeded in 24-well plates and transfected for $5 \mathrm{~h}$ with $200 \mathrm{ng}$ of pGL3 basic or pGL3-survivin-luciferase plasmid using Effectene transfection reagent according to the manufacturer's protocol (Qiagen Inc., Valencia, CA). For all luciferase assays the cells were then incubated for $18 \mathrm{~h}$ in DMEM in the presence of vehicle (DMSO) or $50 \mu \mathrm{g} / \mathrm{ml}$ of EGCG. Cells were assayed for luciferase activity using a luciferase assay kit (Promega, Madison, WI) and light intensity was determined with a luminometer. The data shown were normalized with $\mu \mathrm{g}$ protein.

$R T-P C R$. Total RNA was isolated from MCF-7 cells using TRIzol reagent as described by the manufacturer (Invitrogen. Carlsbad, CA), and quantified by UV absorbance. The reverse transcription and PCR were performed using the superscript system for first-strand cDNA synthesis and PCR Supermix (Invitrogen), respectively. The reverse transcription of RNA was performed in a final volume of $20 \mu \mathrm{l}$ containing $1 \mathrm{X}$ PCR buffer, $2.5 \mathrm{mM} \mathrm{MgCl}_{2}, 0.5 \mathrm{mM}$ dNTP mix, $10 \mathrm{mM}$ DTT, $10 \mathrm{U}$ of SuperScript II, $25 \mathrm{ng} / \mu 1$ oligo (dT), $1 \mu \mathrm{g}$ of total RNA and DEPC-treated water. After incubation at $42^{\circ} \mathrm{C}$ for $50 \mathrm{~min}$, the reaction was terminated by raising the temperature to $70^{\circ} \mathrm{C}$ for $15 \mathrm{~min}$. For PCR, Supermix containing $200 \mathrm{nM}$ of primers was added to $1 \mu \mathrm{l}$ of the newly synthesized cDNA to bring the final volume to $25 \mu \mathrm{l}$. The reaction mixture was first heated at $94^{\circ} \mathrm{C}$ for 5 min and amplification was carried out in 35 cycles at $94^{\circ} \mathrm{C}$ for $30 \mathrm{sec}, 58^{\circ} \mathrm{C}$ for $30 \mathrm{sec}$, and $72^{\circ} \mathrm{C}$ for $30 \mathrm{sec}$, followed by a final incubation at $72^{\circ} \mathrm{C}$ for $5 \mathrm{~min}$, with a Perkin-Elmer 2400 Thermocycler (Perkin-Elmer, Norwalk, CT). The oligonucleotide primers specific for survivin and GAPDH (survivin: forward primer, 5'-TGCCCCGACGTTGCC-3'; reverse primer, 5'-CAGTTCTTGAATGTAGAGATGCGGT-3'; GAPDH: forward primer, 5'-GAAGGTGAAGGTCGGAGTC-3'; reverse primer, 5'-GAAGATGGTGATGGGATTTC-3') were used $(41,42)$. PCR products were fractionated on $2 \%$ agarose gel and visualized with ethidium bromide staining.

Western blot analysis and kinase assay. MCF-7 cells were harvested in sonicating buffer $(62.5 \mathrm{mM}$ Tris-HCl, $\mathrm{pH} 6.8$, $4 \%$ (w/v) SDS, $10 \%$ glycerol, $1 \mathrm{mM}$ phenylmethylsulfonyl fluoride, $25 \mu \mathrm{g} / \mathrm{ml}$ leupeptin, $2.5 \mu \mathrm{g} / \mathrm{ml}$ aprotinin and $1 \mathrm{mM} \mathrm{Na}$ orthovanadate) sonicated for $30 \mathrm{sec}$. Following centrifugation at $1000 \mathrm{x} \mathrm{g}$ for $20 \mathrm{~min}, 50 \mu \mathrm{g}$ of protein was resuspended in sample buffer [62.5 M Tris- $\mathrm{HCl}, \mathrm{pH} 6.8,2 \%(\mathrm{w} / \mathrm{v}) \mathrm{SDS}$, $10 \%$ glycerol, $5 \%$ mercaptoethanol, $0.01 \%$ bromophenol blue], boiled for $5 \mathrm{~min}$. Denatured proteins were separated by electrophoresis on a SDS-polyacrylamide gel. Proteins were transferred to nitrocellulose membrane (Bio-Rad Hercules, $\mathrm{CA}$ ) in $20 \mathrm{mM}$ Tris base, $150 \mathrm{mM}$ glycine, and $20 \% \mathrm{v} / \mathrm{v}$ 
A

B
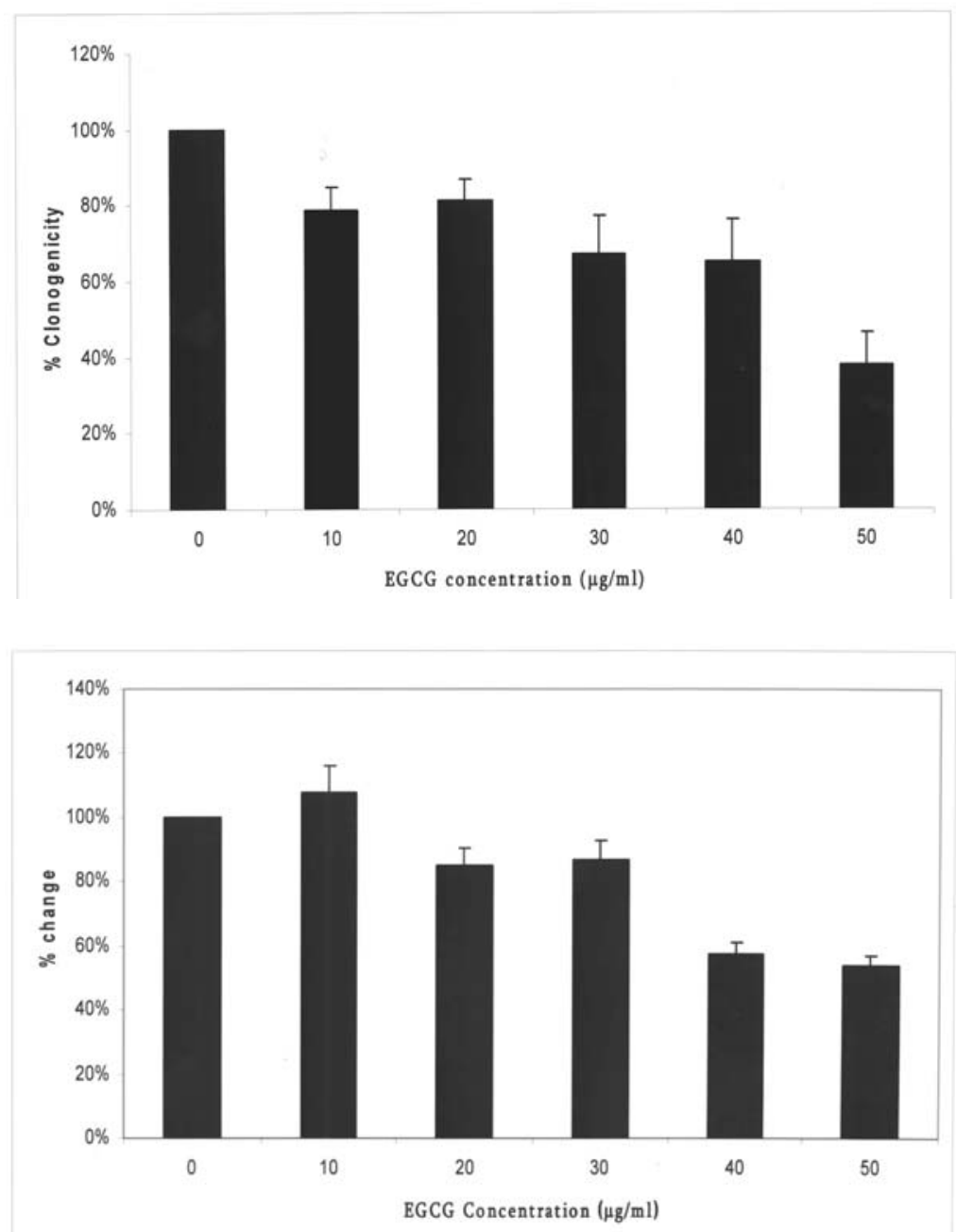

C

Control

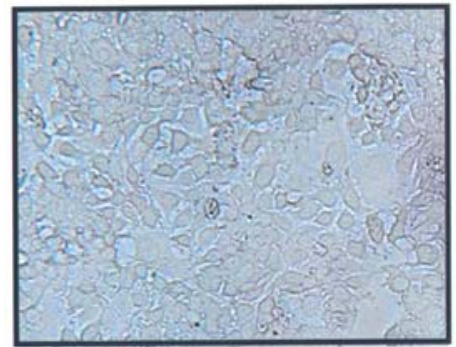

$10 \times B F$

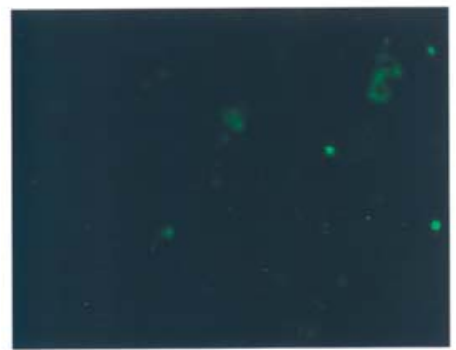

$10 \mathrm{xFLG}$
$50 \mu \mathrm{g} \mathrm{EGCG}$

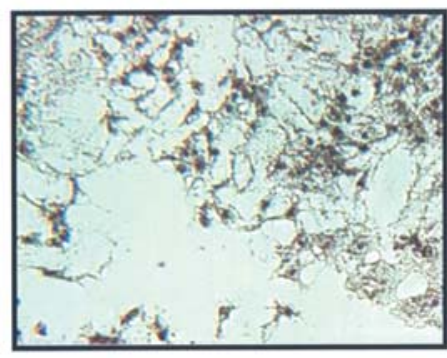

$10 \mathrm{xBF}$



10xFLG

Figure 1. A, EGCG reduces survival of MCF-7 cells. A, colony survival inhibition of MCF-7 cells. Cells were treated with vehicle (DMSO) or EGCG (10$50 \mathrm{mg} / \mathrm{ml}$ ) for 2 days then cultured for 2 weeks. See details in Materials and methods. The data represent means \pm SEM ( $=9$ ). B, viability inhibition of MCF-7 cells. Cells $\left(1 \times 10^{4}\right) /$ well were plated in 96-well plates and treated with DMSO or EGCG (10-100 mg/ml) for 2 days, and stained with 0.5\% crystal violet. Cells were lysed with $1 \%$ SDS and absorption was obtained at $540 \mathrm{~nm}$. The data represent means \pm SEM ( $=9$ ). C, apoptosis induction in MCF-7 cells. MCF-7 cells ( $80 \%$ confluent) in a 4-well chamber slide were treated with EGCG $(50 \mathrm{mg} / \mathrm{ml})$ or not for 2 days. Cells were washed twice with PBS and then stained by an Annexin-V apoptosis detection kit (Molecular Probes) as instructed by the manufacturer's protocol. FITC-stained apoptotic cells were demonstrated in fluorescence microscopy (x10). 
methanol for $100 \mathrm{~V} / \mathrm{h}$. Non-specific binding was blocked by incubating the blot with PBS-Tween (0.05\%)-5\% low-fat dry milk solution for $1 \mathrm{~h}$ at room temperature. The membrane was subsequently incubated overnight at $4^{\circ} \mathrm{C}$ with rabbit survivin monoclonal antibodies, 1:1000 dilution (Pharmingen, San Diego, CA), phospho-AKT antibody (Cell Signaling Technology, Beverly, MA), caspase-9, (Oncogene, San Diego, CA) and $B$-actin (Sigma). Blots were washed in PBSTween solution and incubated with goat anti-rabbit antibodies conjugated to horseradish peroxidase $(1: 10,000$ dilution; Gaithersburg, MD) for $60 \mathrm{~min}$ at room temperature. Following washes with PBS-Tween solution, immunoreactive proteins were visualized with ECL reagent (Amersham, Arlington Heights, IL) and then exposed to Hyperfilm (Amersham).

AKT kinase activity assays were performed according to the manufacturer's instructions (Cell Signaling Technology). Briefly, cell lysates with $200 \mu \mathrm{g}$ protein from EGCG-treated MCF-7 cells with treatment times ranging from 0.5 to $24 \mathrm{~h}$ or from untreated $(0 \mathrm{~h})$ cells. Cells were mixed with immobilized AKT antibody slurry overnight at $4^{\circ} \mathrm{C}$. Immunoprecipitated protein was washed twice with ice-cold lysis and kinase buffer, then incubated with $1 \mu \mathrm{g}$ GSK-3 fusion protein and $200 \mu \mathrm{M}$ ATP for $30 \mathrm{~min}$ at $30^{\circ} \mathrm{C}$. The reaction was terminated by adding $3 \mathrm{X}$ SDS sample buffer and boiling for $5 \mathrm{~min}$. The sample $(30 \mu 1)$ was loaded on $12 \%$ SDS-PAGE gel. Specific band was identified by anti-phospho- $3 \alpha / 3$ SK fusion protein antibodies, and visualized as described above.

Statistical analysis. Statistical differences in colony formation, and survivin promoter activity with or without EGCG were determined by a Student's t-test, and the data are expressed as means \pm SEM.

\section{Results}

The effect of EGCG on cell colony formation in a dosedependent manner is shown in Fig. 1A. When MCF-7 cells were treated with 10 or $30 \mu \mathrm{g} / \mathrm{ml}$ of EGCG, colony survival was reduced to 79 and $67 \%$ respectively as compared to untreated control plates (100\%). At $50 \mu \mathrm{g} / \mathrm{ml}$ of EGCG the percent of colony survival was significantly reduced to $38 \% \pm 8 \%(\mathrm{P}<0.001)$. When treated with $100 \mu \mathrm{g} / \mathrm{ml}$ of EGCG, all the cells were unable to form visible colonies. The ability of EGCG to affect long-term colony formation may be in part through both suppression of and/or induction of cell death. The effects of EGCG on cellular viability of MCF-7 cells were detected with a crystal violet assay (Fig. 1B). As shown in Fig. 1B, a similar and significant dose-dependent inhibition of cell proliferation was observed with $24-\mathrm{h}$ treatment with EGCG $(\mathrm{P}<0.001)$, reducing viability to $68 \%$ when compared with untreated control group.

Using Annexin-V apoptosis detection kits the untreated and treated MCF-7 cells were tested for apoptosis induced by EGCG. Fifty $\mu \mathrm{g} / \mathrm{ml}$ EGCG was able to induce apoptosis in MCF-7 as detected in Annexin- $\mathrm{V}$ binding assay, indicating EGCG as a potent inducer of apoptosis in MCF-7 cells (Fig. 1C).

The mechanisms involved in the inhibition of growth and induction of apoptosis by EGCG have not been fully explored. To test whether EGCG-induced apoptosis of MCF-7 cells
A
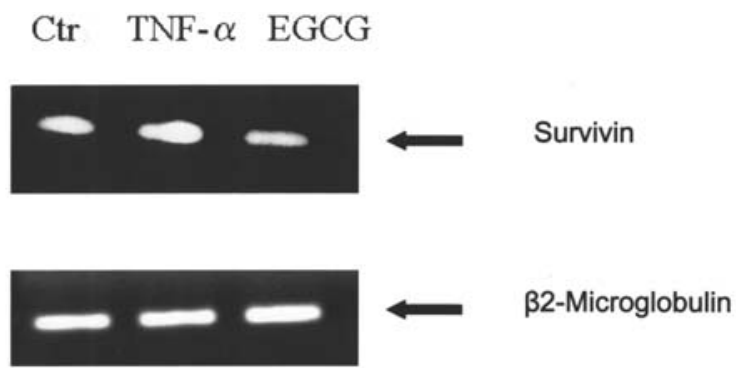

B



Figure 2. A, suppression of expression of both protein and mRNA in MCF-7 cells. Cells were preincubated with $50 \mathrm{mg} / \mathrm{ml}$ EGCG for $24 \mathrm{~h}$. Cell lysates were obtained as described in Materials and methods. Control (Ctr) treatments were with vehicle (DMSO) or $1 \mathrm{ng} / \mathrm{ml}$ tumor necrosis factor alpha (TNF- $\alpha$ ). One mg RNA or $50 \mathrm{mg}$ protein was used for RT-PCR or Western blot analyses, respectively. B, prevention of transactivation of survivin promoter. Cells (in 24-well plates) were transfected with $200 \mathrm{ng}$ of pGL3-survivinluciferase plasmid (SP13) using Effectene transfection reagent according to the manufacturer's protocol (Qiagen) for $5 \mathrm{~h}$, and treated with vehicle (DMSO) or $50 \mathrm{mg} / \mathrm{ml}$ of EGCG for $18 \mathrm{~h}$. Luciferase activity was obtained using $30 \mathrm{ml}$ of cell extract. The data were normalized per microgram protein. The data represent four replicates.

involves altered survivin expression, RT-PCR and Western blotting were used to detect endogenous production of survivin mRNA and survivin protein. As shown in Fig. 2A, a high level expression of survivin mRNA and survivin were observed in MCF-7 cells (Fig. 2A, control lane) which was minimally affected by $1 \mathrm{ng} / \mathrm{ml} \mathrm{TNF}-\alpha$ (Fig. 2A, lane 2). In contrast, $50 \mu \mathrm{g} / \mathrm{ml} \mathrm{EGCG}$ treatment for $24 \mathrm{~h}$ (Fig. 2A, lane 3) strongly inhibited both survivin mRNA and protein expression as compared to control and TNF- $\alpha$-treated groups. Using a reporter construct of the survivin promoter linked to luciferase we further demonstrated that treatment of $\mathrm{MCF}-7$ cells with $50 \mu \mathrm{g} / \mathrm{ml}$ of EGCG for $18 \mathrm{~h}$ reduced promoter activity by $91 \pm 2.0 \%$ as compared to DMSO-treated controls (100\%) (Fig. 2B) $(\mathrm{P}<0.001)$.

Survivin has been demonstrated to be up-regulated by the AKT signaling pathway (43). To test the hypothesis that the AKT signal transduction pathway is involved in the survivin promoter regulation, a DN-AKT was transfected into MCF-7 cells. As demonstrated in Fig. 3, a trans-activation survivin promoter in SP13-transfected MCF-7 cells was significantly inhibited by DN-AKT. Furthermore, LY294002 (30 $\mu \mathrm{M})$, a specific inhibitor of the phosphatidylinositol 3-kinase (PI3K)/ AKT signal transduction pathway, was able to significantly block the transactivation of survivin promoter (Fig. 3) $(\mathrm{P}<0.01)$. 


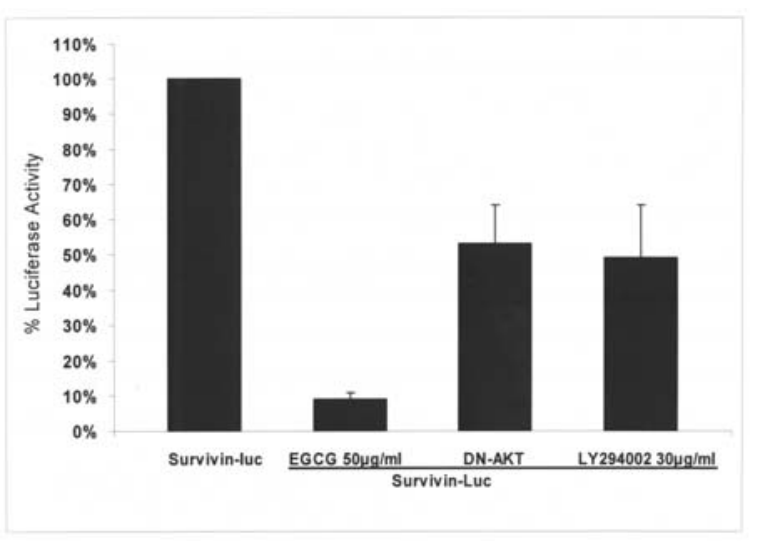

Figure 3. DN-AKT and P13K inhibitor (LY294002) blocks transactivation of a transiently transfected pGL3 survivin-luciferase. Cells were transfected with $100 \mathrm{ng}$ of DN-AKT plasmid and $200 \mathrm{ng}$ of pGL3-survivin-luciferase plasmid for $5 \mathrm{~h}$, and grown for $18 \mathrm{~h}$. In AKT inhibitor assay, cells were transfected with $200 \mathrm{ng}$ pGL3-survivin-luciferase plasmid for $5 \mathrm{~h}$, and treated with $30 \mathrm{mmol}$ LY294002 for $18 \mathrm{~h}$. Luciferase activity was obtained using $30 \mathrm{ml}$ of cell extract. The data were normalized per microgram protein.

In order to investigate whether the AKT pathway is involved in survivin inhibition induced apoptosis by EGCG, phosphorylated AKT expression levels were determined by Western blot analysis with specific anti-phospho-AKT (Ser-473) antibodies (Fig. 4). Expression of survivin and levels of phosphorylated AKT in control and TNF- $\alpha$ treatment groups were similar. However, both survivin and phosphorylated AKT were obviously decreased in the EGCG-treated group.

The relationship between AKT and survivin and apoptosis in MCF-7 cells treated with EGCG was studied using Western blot assays as demonstrated in Fig. 5. Akt kinase activity was assessed using immunoprecipitates from cellular extracts obtained with total AKT antibody and GSK-3 as a substrate. Interestingly, AKT activity dramatically decreased in $30 \mathrm{~min}$ after treatment with EGCG and the effect lasted for $24 \mathrm{~h}$. However, survivin was not immediately inhibited by EGCG until $3 \mathrm{~h}$ after the treatment. Activated caspase- 9 accumulated at $6 \mathrm{~h}$.

\section{Discussion}

In this study we demonstrated that EGCG effectively inhibited colony formation and induced apoptosis of MCF-7 breast cancer cells via down-regulation of survivin, a major member of the IAP gene family.

EGCG, one of the most important polyphenols in green tea, is demonstrated to be a potent growth suppressor of certain cancer xenografts, as well as decreasing tumor vessel density in vivo and in vitro $(22,23)$. The inhibition of cell growth and the induction of apoptosis by EGCG have been demonstrated in a number of cell lines $(1,44)$. EGCG $(2-5 \mu \mathrm{M})$ inhibited TPA- or EGF-induced transformation by inhibition of AP-1 transcriptional activity $(24,37)$. In this experiment, treatment of MCF-7 cells with EGCG for $48 \mathrm{~h}$ resulted in a dose-dependent inhibition of colony formation (Fig. 1A and B). Doses as low as $50 \mu \mathrm{g} / \mathrm{ml}$ of EGCG significantly inhibited colony formation in these cells $(\mathrm{P}<0.01)$. As mentioned above, the inhibitory effect of EGCG was tumor-specific and was not observed in
CTR TNF $\alpha$ EGCG

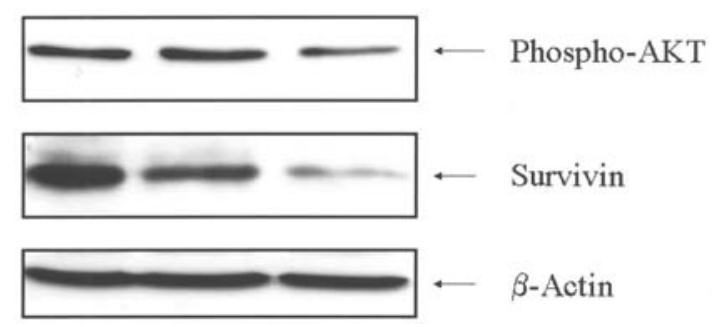

Figure 4. EGCG inhibits both phospho-AKT and survivin expression in MCF-7 cells. Cells were treated with $50 \mathrm{mg} / \mathrm{ml}$ of EGCG for $24 \mathrm{~h}$, and phosphorylation of AKT in Western blotting was detected using a phosphospecific antibody. Control (CTR) treatments were with vehicle (DMSO) or $1 \mathrm{ng} / \mathrm{ml}$ tumor necrosis factor alpha $(\mathrm{TNF}-\alpha)$. B-actin served as control of Western blotting.



Figure 5. Effects of EGCG on AKT kinase activity, survivin and activated caspase-9 expression in MCF-7 cells. Cells were treated with $50 \mathrm{mg} / \mathrm{ml}$ of EGCG for different times. Protein $(200 \mathrm{mg})$ of cell lysate was used for AKT kinase activity assay according to the manufacturer's instruction (Cell Signaling). For survivin and caspase-9, $50 \mathrm{mg}$ of protein was used for Western blotting and B-actin as internal control.

the normal counterparts of the tumor cell line (20). Our study suggests and supports the previous results that EGCG is a potent in vitro inhibitor of MCF-7 cell growth at $50 \mu \mathrm{g} / \mathrm{ml}$.

The mechanism of EGCG effects on colony formation of cultured cancer cells has not been adequately explored except for a few published results that associated the inhibition of neoplastic proliferation by EGCG with evidence of blocking effects on Her2/Neu signaling (45), G1/S arrest by induction of p21 (CIP1/WAF1/SDI), inhibition of cyclin D1-associated pRB kinase activity, or impairment of pRB phosphorylation (46). Details of cell cycle control by EGCG, however, are still not well understood. Early studies with EGCG in a breast cancer cell line suggested that it could induce apoptosis (47), and new results linked growth inhibition with the induction of apoptosis by EGCG (48-51), but the effective concentration is higher than that required for growth inhibition. Consistent with previous reports on breast cancer cells (44), accompanied with our observation demonstrating reduced colony formation, a dramatic increase in apoptosis was observed in EGCGtreated MCF-7 cells (50 $\mu \mathrm{g} / \mathrm{ml}$ ) (Fig. 1B and 1C). Molecular evidence of induction of apoptosis in MCF-7 cells by EGCG was provided at different levels of the apoptotic signaling 
pathways in our study. First, a high basal level of survivin mRNA and protein (Fig. 2A, control lanes) were present in cultured MCF-7 cells that is consistent with previous reports that cultured breast cancer cells express high levels of survivin (34-36,52). The level of constitutive survivin mRNA and protein (Fig. 2A) in MCF-7 cells was minimally inhibited by TNF- $\alpha$ (Fig. 2A, lane 2), a potent apoptotic inducer in many cells, but significantly inhibited by EGCG (50 $\mu \mathrm{g} / \mathrm{ml})$ (Fig. 2A, lane 3), which may suggest the presence of a different pathway of apoptosis induced by EGCG. Interestingly, EGCG seems to exert its effect on the trans-inhibition of survivin promoter activity (Fig. 2B). Finally, an increase in activated caspase-9 levels was observed after 6-h treatment with EGCG $(50 \mu \mathrm{g} / \mathrm{ml})$ (Fig. 5, lane 5), consistent with apoptosis.

Akt is a serine (Ser)/threonine (Thr) protein kinase which resides within the cytosol in a catalytically inactive state in quiescent or serum-starved cells. After stimulation of cells with growth factors and cytokines, Akt is catalytically activated by phosphorylation at Thr308 and Ser473. Activated Akt in turn phosphorylates downstream target molecules such as BAD which promote induction of its anti-apoptosis effect (53-55). Most interestingly survivin was upregulated by the AKT signaling pathway (43). We confirmed that the pharmacological inhibitor of the PI3K/AKT pathway (LY294002) (56) or a dominant-negative Akt (K179M) strongly inhibited survivin expression and survivin promoter activity in MCF-7 cells (Fig. 5). Interestingly, EGCG also strongly inhibited phosphorylation of AKT and AKT kinase activity in MCF-7 cells (Figs. 4 and 5), suggesting that EGCG induces apoptosis in MCF-7 cells by inhibiting constitutive activation of AKT and subsequent survivin expression. Taken together, these results strongly suggest that decreased expression of PI3K/ AKT is a necessary step for the negative regulation of survivin gene expression by EGCG.

Human caspase-9, a member of the protease family intimately associated with the initiation of apoptosis, is able to be phosphorylated and inhibited by Akt (60). We demonstrated the time course of caspase- 9 activation after treatment of EGCG at $6 \mathrm{~h}$, compared with control, preceded by the decrease in phosphorylated Akt (30 min), and decreased expression of survivin ( $3 \mathrm{~h}$ post-exposure). The time course of inhibition of AKT kinase acitivity, suppression of survivin, and activated caspase-9 in response to EGCG strongly suggests that the inhibitory effect of EGCG on breast cancer cell growth results from induction of apoptosis via an AKTsurvivin-dependent mechanism.

Survivin is one of the specific classes of inhibitors of apoptosis proteins (IAPs), and plays a pivotal role in tumor proliferation and resistance to chemotherapy or radiation therapy in breast cancers. In this study we demonstrated that inhibition of survivin either directly or indirectly by EGCG is a key step in the molecular mechanism involved in the antiproliferative and proapoptotic effects of green tea which may contribute to its potential use for breast cancer therapy and/or prevention.

\section{References}

1. Imai K, Suga K and Nakachi K: Cancer-preventive effects of drinking green tea among a Japanese population. Prev Med 26: $769-775,1997$.
2. Kazi A, Smith DM, Daniel K, Zhong S, Gupta P, Bosley ME and Dou QP: Potential molecular targets of tea polyphenols in human tumor cells: significance in cancer prevention. In Vivo 16: 397-403, 2002.

3. Chen A and Zhang L: The antioxidant epigallocatechin-3gallate inhibits rat hepatic stellate cells proliferation in vitro by blocking the tyrosine phosphorylation and reducing the gene expression of platelet-derived growth factor- $\beta$ receptor. J Biol Chem 278: 23381-23389, 2003.

4. Gupta S, Hastak K, Ahmad N, Lewin JS and Mukhtar H: Inhibition of prostate carcinogenesis in TRAMP mice by oral infusion of green tea polyphenols. Proc Natl Acad Sci USA 98: 10350-10355, 2001

5. Balentine DA, Wiseman SA and Bouwens LCM: The chemistry of tea flavonoids. Crit Rev Food Sci Nutr 37: 693-704, 1997.

6. Wiseman SA, Balentine DA and Frei B: Antioxidants in tea. Crit Rev Food Sci Nutr 37: 705-718, 1997.

7. Yang CS, Chen L, Lee M-J, Balentine D, Kuo MC and Schantz SP: Blood and urine levels of tea catechins after ingestion of different amounts of green tea by human volunteers. Cancer Epidemiol Biomarkers Prev 7: 351-354, 1998.

8. Nakagawa K, Okuda S and Miyazawa T: Dose-dependent incorporation of tea catechins, (-)-epigallocatechin-3-gallate and (-)-epigallocatechin, into human plasma. Biosci Biotechnol Biochem 61: 1981-1985, 1997.

9. Linden KG, Carpenter PM, McLaren CE, Barr RJ, Hite P, Sun JD, Li KT, Viner JL and Meyskens FL: Chemoprevention of non-melanoma skin cancer: experience with a polyphenol from green tea. Recent Results Cancer Res 163: 165-171, 2003.

10. Adhami VM, Ahmad N and Mukhtar H: Molecular targets for green tea in prostate cancer prevention. J Nutr 133: S2417-S2424, 2003.

11. Zhang H, Spitz MR, Tomlinson GE, Schabath MB, Minna JD and $\mathrm{Wu} \mathrm{X}$ : Modification of lung cancer susceptibility by green tea extract as measured by the comet assay. Cancer Detect Prev 26: 411-418, 2002.

12. Guyton KZ and Kensler TW: Prevention of liver cancer. Curr Oncol Rep 4: 464-470, 2002.

13. Kemberling JK, Hampton JA, Keck RW, Gomez MA and Selman SH: Inhibition of bladder tumor growth by the green tea derivative epigallocatechin-3-gallate. J Urol 170: 773-776, 2003.

14. Sato D and Matsushima M: Preventive effects of urinary bladder tumors induced by N-butyl-N-(4-hydroxybutyl)-nitrosamine in rat by green tea leaves. Int J Urol 10: 160-166, 2003.

15. Hoshiyama Y, Kawaguchi T, Miura Y, Mizoue T, Tokui N, Yatsuya H, Sakata K, Kondo T, Kikuchi S, Toyoshima H, Hayakawa N, Tamakoshi A, Ohno Y and Yoshimura T: Japan Collaborative Cohort Study Group: a prospective study of stomach cancer death in relation to green tea consumption in Japan. Br J Cancer 87: 309-313, 2002.

16. Jung YD, Kim MS, Shin BA, Chay KO, Ahn BW, Liu W, Bucana CD, Gallick GE and Ellis LM: EGCG, a major component of green tea, inhibits tumour growth by inhibiting VEGF induction in human colon carcinoma cells. Br J Cancer 84: 844-850, 2001.

17. Isemura M, Saeki K, Kimura T, Hayakawa S, Minami T and Sazuka M: Tea catechins and related polyphenols as anti-cancer agents. Biofactors 13: 81-85, 2000.

18. Hiura A, Tsutsumi M and Satake K: Inhibitory effect of green tea extract on the process of pancreatic carcinogenesis induced by $\mathrm{N}$-nitrosobis-(2-oxypropyl)amine (BOP) and on tumor promotion after transplantation of N-nitrosobis-(2-hydroxypropyl)amine (BHP)-induced pancreatic cancer in Syrian hamsters. Pancreas 15: 272-277, 1997.

19. Ji BT, Chow WH, Hsing AW, McLaughlin JK, Dai Q, Gao YT, Blot WJ and Fraumeni JF Jr: Green tea consumption and the risk of pancreatic and colorectal cancers. Int J Cancer 70: 255-258, 1997.

20. Wang YC and Bachrach U: The specific anti-cancer activity of green tea (-)-epigallocatechin-3-gallate (EGCG). Amino Acids 22: 131-143, 2002.

21. Wu AH, Yu MC, Tseng CC, Hankin J and Pike MC: Green tea and risk of breast cancer in Asian Americans. Int J Cancer 106: 574-579, 2003.

22. Chung SY, Maliakal P and Meng X: Inhibition of carcinogenesis by tea. Annu Rev Pharmacol Toxicol 42: 25-54, 2002.

23. Yeh CW, Chen WJ, Chiang CT, Lin-Shiau SY and Lin JK: Suppression of fatty acid synthase in MCF-7 breast cancer cells by tea and tea polyphenols: a possible mechanism for their hypolipidemic effects. Pharmacogenomics J 3: 267-276, 2002. 
24. Masuda M, Suzui M, Lim JT, Deguchi A, Soh JW and Weinstein IB: Epigallocatechin-3-gallate decreases VEGF production in head and neck and breast carcinoma cells by inhibiting EGFR-related pathways of signal transduction. J Exp Ther Oncol 2: 350-359, 2002.

25. Yamamoto T, Hsu S, Lewis J, Wataha J, Dickinson D, Singh B, Bollag WB, Lockwood P, Ueta E, Osaki T and Schuster G: Green tea polyphenol causes differential oxidative environments in tumor versus normal epithelial cells. J Pharmacol Exp Ther 307: 230-236, 2003.

26. Chung JH, Han JH, Hwang EJ, Seo JY, Cho KH, Kim KH, Youn JI and Eun HC: Dual mechanisms of green tea extract (EGCG)-induced cell survival in human epidermal keratinocytes. FASEB J 17: 1913-1915, 2003.

27. Chiou SK, Jones MK and Tarnawski AS: Survivin an antiapoptosis protein: its biological roles and implications for cancer and beyond. Med Sci Monit 9: PI25-PI29, 2003.

28. Ambrosini G, Adida C and Alteieri DC: A novel antiapoptosis gene, survivin, expressed in cancer and lymphoma. Nat Med 3: 917-921, 1997.

29. Mahotka C, Wenzel M, Springer E, Gabbert HE and Gerharz CD: Survivin- $\triangle \mathrm{Ex} 3$ and survivin-2B: two novel splice variants of the apoptosis inhibitor survivin with different antiapoptotic properties. Cancer Res 59: 6097-6102, 1999.

30. Tamm I, Wang Y, Sausville E, Scudiero DA, Vigna N, Oltersdorf T and Reed JC: IAP-family protein survivin inhibits caspase activity and apoptosis induced by FAS (CD95), Bax, caspases, and anticancer drugs. Cancer Res 58: 5315-5320, 1998.

31. Suzuki A, Ito T, Kawano H, Hayashida M, Hayasaki Y, Tsutomi Y, Akahane K, Nakano T, Miura M and Shiraki K: Survivin initiates procaspase 3/p21 complex formation as a result of interaction with cdk4 to resist Fas-mediated cell death. Oncogene 19: 1346-1353, 2000.

32. Zaffaroni N, Pennati M, Colella G, Perego P, Supino R, Gatti L, Pilotti S, Zunino F and Daidone MG: Expression of the antiapoptotic gene survivin correlates with taxol resistance in human ovarian cancer. Cell Mol Life Sci 59: 1406-1412, 2002.

33. Vergote D, Cren-Olive C, Chopin V, Toilion RA, Rolando C, Hondermarck H and Bourhis XL: Epigallocatechin (EGC) of green tea induces apoptosis of human breast cancer cells but not of their normal counterparts. Breast Cancer Res Treat 76: 195-201, 2002.

34. Kennedy SM, O'Driscoll L, Purcell R, Fitz-Simons N, McDermott EW, Hill AD, O'Higgins NJ, Parkinson M, Linehan R and Clynes M: Prognostic importance of survivin in breast cancer. Br J Cancer 88: 1077-1083, 2003.

35. Singh M, Bleile MJ, Shroyer AL, Heinz D, Jarboe EA and Shroyer KR: Analysis of survivin expression in a spectrum of benign to malignant lesions of the breast. Appl Immunohistochem Mol Morphol 12: 296-304, 2004.

36. Tanaka K, Iwamoto S, Gon G, Nohara T, Iwamoto $M$ and Tanigawa N: Expression of survivin and its relationship to loss of apoptosis in breast carcinomas. Clin Cancer Res 4: 127-134, 2000.

37. Chan HY, Wang H, Tsang DS, Chen ZY and Leung LK: Screening of chemopreventive tea polyphenols against PAH genotoxicity in breast cancer cells by a XRE-luciferase reporter construct. Nutr Cancer 46: 93-100, 2003.

38. Dohi T, Beltrami E, Wall NR, Plescia J and Altieri DC: Mitochondrial survivin inhibits apoptosis and promotes tumorigenesis. J Clin Invest 114: 1117-1127, 2004.

39. Burow ME, Weldon CB, Tang Y, Navar GL, Krajewski S, Reed JC, Hammond TG, Clejan S and Beckman BS: Differences in susceptibility to tumor necrosis factor alpha-induced apoptosis among MCF-7 breast cancer cell variants. Cancer Res 58: 4940-4946, 1998.
40. Mirza A, McGuirk M, Hockenberry TN, Wu Q, Ashar H, Black S, Wen SF, Wang L, Kirschmeier P, Bishop WR, Nielsen LL, Pickett CB and Liu S: Human survivin is negatively regulated by wild-type p53 and participates in p53-dependent apoptotic pathway. Oncogene 21: 2613-2622, 2002.

41. Wen SF, Xie L, McDonald M, Di Giacomo R, Chang A, Gurnani M, Shi B, Liu S, Indelicato SR, Hutchins B and Nielsen LL: Development and validation of sensitive assays to quantitate gene expression after p53 gene therapy and paclitaxel chemotherapy using in vivo dosing in tumor xenograft models. Cancer Gene Ther 7: 1469-1480, 2000.

42. Ikeguchi M and Kaibara N: Survivin messenger RNA expression is a good prognostic biomarker for oesophageal carcinoma. Br J Cancer 87: 883-887, 2002.

43. Mitsiades CS, Mitsiades N, Poulaki V, Schlossman R, Akiyama M, Chauhan D, Hideshima T, Treon SP, Munshi NC, Richardson PG and Anderson KC: Activation of NF-kappaB and upregulation of intracellular anti-apoptotic proteins via the IGF-1/Akt signaling in human multiple myeloma cells: therapeutic implications. Oncogene 21: 5673-5683, 2002.

44. Suganuma M, Okabe S, Sueoka N, Sueoka E, Matsuyama S, Imai K, Nakachi K and Fujiki H: Green tea and cancer chemoprevention. Mutat Res 428: 339-344, 1999.

45. Pianetti S, Guo S, Kavanagh KT and Sonenshein GE: Green tea polyphenol epigallocatechin 3 gallate inhibits Her-2/Neu signaling, proliferation, and transformed phenotype of breast cancer cells. Cancer Res 62: 652-655, 2002.

46. Liberto $\mathrm{M}$ and Cobrinik D: Growth factor-dependent induction of p21(CIP1) by the green tea polyphenol, epigallocatechin gallate. Cancer Lett 154: 151-161,2000.

47. Lin JK, Liang YC and Lin-Shiau SY: Cancer chemoprevention by tea polyphenols through mitotic signal transduction blockade. Biochem Pharmacol 58: 911-915, 1999.

48. Yanaga H, Fujii T, Koga T, Araki R and Shirouzu K: Prevention of carcinogenesis of mouse mammary epithelial cells RIII/MG by epigallocatechin gallate. Int J Mol Med 10: 311-315, 2002.

49. McCarty MF: Polyphenol-mediated inhibition of AP-1 transactivating activity may slow cancer growth by impeding angiogenesis and tumor invasiveness. Med Hypotheses 50: 511-514, 1998.

50. Dong Z, Ma W, Huang C and Yang CS: Inhibition of tumor promoter-induced activator protein 1 activation and cell transformation by tea polyphenols, (-)-epigallocatechin gallate, and theaflavins. Cancer Res 57: 4414-4419, 1997.

51. Ahmad N, Feyes DK, Nieminen A-L, Agarwal R and Mukhtar H: Green tea constituent epigallocatechin-3-gallate and induction of apoptosis and cell cycle arrest in human carcinoma cells. J Natl Cancer Inst 89: 1881-1886, 1997.

52. Mukhtar H and Ahmad N: Mechanism of cancer chemopreventive activity of green tea. Proc Soc Exp Biol Med 220: 234-238, 1999.

53. Hideshima T, Nakamura N, Chauhan D and Anderson KC: Biologic sequelae of interleukin-6 induced PI3-K/Akt signaling in multiple myeloma. Oncogene 20: 5991-6000, 2001.

54. Yaffe MB, Rittinger K, Volinia S, Caron PR, Aitken A, Leffers H, Gamblin SJ, Smerdon SJ and Cantley LC: The structural basis for 14-3-3:phosphopeptide binding specificity. Cell 91: 961-971, 1997.

55. Burow ME, Weldon CB, Collins-Burow BM, Ramsey N, McKee A, Klippel A, McLachlan JA, Clejan S and Beckman BS: Cross-talk between phosphatidylinositol 3-kinase and sphingomyelinase pathways as a mechanism for cell survival/death decisions. J Biol Chem 31: 9628-9635, 2000.

56. Franke TF and Cantley LC: Apoptosis: a bad kinase makes good. Nature 390: 116-117, 1997. 